Hungarian Educational Research

Journal

\section{Internationalization of Georgian Higher Education: National and International Influences}

Anne Campbell ${ }^{7}$ \& Sophia Gorgodze 8
2016, Vol. 6(1) 21-36

(C) The Author(s) 2016

http://herj.lib.unideb.hu

Debrecen University Press

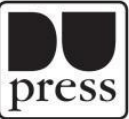

DOI:10.14413/HERJ.2016.01.02

\begin{abstract}
In response to the scant academic research about higher education internationalization in Eastern Europe and the Caucasus, this paper investigates the characteristics and influences of internationalization in the Republic of Georgia. Based on interviews with Georgian government representatives and university faculty and administrators, this research identified the perceived benefits of internationalization and the effectiveness of its implementation. The research findings indicate that three main engines are driving internationalization in Georgia: western influences through modeling and international programs; national higher education accreditation processes; and the academic programs, courses, and partnerships developed by internationally-mobile Georgian faculty and students. In addition, two recent opportunities for additional growth in internationalization are described - international students in Georgia and joint and dual degrees - along with recommendations on how to further enhance internationalization efforts.
\end{abstract}

Keywords: higher education, international education, universities, educational quality, university accreditation, faculty mobility, student mobility, Georgia

\footnotetext{
${ }^{7}$ Anne Campbell, Middlebury Institute of International Studies, Monterey (USA), accampbell@miis.edu

${ }^{8}$ Sophia Gorgodze, Ilia State University, Tbilisi (Georgia), sopho_gorgodze@iliauni.edu.ge
} 


\section{Introduction}

The landscape of Georgian higher education was vastly different before and after independence from the Soviet Union in 1991. During the Soviet times, a central government controlled the number of universities and programs offered in the Republic. Following independence, the number of universities skyrocketed in the absence of quality assurance mechanisms and the presence of widespread corruption, as university licensing and admissions provided additional income to underfunded institutions (Janashia, 2004). As more Georgians pursued highly valued university education, private higher education institutions of questionable quality could be found in the buildings of kindergartens and schools, hospitals, and former factories (National Center for Educational Accreditation, 2006). At the time of independence, Georgia hosted 19 universities, but this number increased to 26 public and 214 private institutions by 2005 (Sharvashidze, 2005).

Simultaneously, international aid programs and projects flowed into the new independent republics to promote a market economy, liberal democracy, and civil society following the collapse of the Soviet Union (Quigley, 1997). Among these initiatives, educational reforms and development programs were of paramount importance (Silova, 2008). With little financial support available from the national budget, Georgian universities accepted funds from private foundations or foreign national governments to modernize and improve the quality of higher education (Sharvashidze, 2005).

In 2004, following a peaceful revolution, and with a new government aiming to usher in a liberal democracy, Georgia pursued a reform agenda to strengthen the quality of higher education in the country. The new administration, headed by President Mikheil Saakashvili, pursued policies and programs that emulated quality higher education systems abroad (Saakashvili, 2006). The government took measures to root out corruption at universities, encouraged university administrators to capitalize on existing international partnerships, and promoted greater exchanges for faculty and students. By setting their sights on European and American higher education models, the government's goals were both to learn from higher education institutions and scholars in the west and to ultimately improve the quality of Georgian higher education (Dobbins \& Khachatryan, 2015). With new accreditation criteria introduced in 2004, the number of universities decreased to 28 accredited private and public universities today (Ministry of Education and Science of Georgia, 2015a).

As the Georgian government and universities seek greater involvement with higher education abroad, it follows logically to explore the ways that Georgian universities have 
responded to the government's reform efforts and are establishing connections with overseas partners today. To best investigate these phenomena, we turn to the concept of higher education internationalization. According to the Altbach and Knight (2007), internationalization is defined as "the policies and practices undertaken by academic systems and institutions - and even individuals - to cope with the global academic environment" (p. 290). The ways that systems, institutions, and individuals engage in internationalization may include curricular enhancements, international partnerships, outbound and international student mobility, the establishment of new English-language programs, and many others (Altbach \& Knight, 2007; Knight, 2012).

To date, no extant research indicates what characteristics define Georgia's internationalization strategy or how Georgian universities themselves are involved in internationalization efforts. This paucity of research is not unusual; in fact, there is little peer-reviewed exploration of higher education internationalization in the former Soviet space. (One notable exception is a 2012 paper by Kushnarenko \& Cojocari on internationalization of higher education in Moldova.)

With this context in mind, the questions that guide this paper are as follows: First, what are the main characteristics of Georgian higher education internationalization? Second, what are the forces that guide internationalization efforts in the country?

\section{Research Methods}

This case study is rooted in a grounded theory approach, with an aim to gather a greater understanding of how internationalization is conceived and the forces that shape this phenomenon in the Republic of Georgia. As the discourse on higher education internationalization is in its early stages in Georgia, we decided to conduct interviews to seek deeper understanding of the concept, related terms, and understanding of the phenomenon.

We conducted interviews with 18 individuals who were selected based on their role as an instructor, administrator, or manager of a program related to international higher education. Fourteen of these were interviews with faculty, administrators, and instructors in international academic departments or international or quality assurance offices at three universities; at Georgian universities, these positions are involved with international partnerships, student exchanges, international research, and ensuring the quality of the university according to international standards. To recruit these interviewees, the heads of departments or units were contacted first and asked to be involved in the research or to recommend a colleague; in most cases, the department or unit head agreed to be interviewed. These universities were selected because they represented the landscape of Georgian higher education: two large public (state) 
universities and one small private university. Six interviewees were based at one large public university, five interviewees were based at a second large public university, and three were based at the small private university. All three universities are located in the capital city of Tbilisi, as the majority of universities and tertiary-level Georgian students are studying in the nation's capital. In addition, four interviews were conducted with administrators or appointed officials in government or international non-governmental organization (NGO) offices that specialize in higher education accreditation and student mobility in Georgia.

For the bulk of the interviews, participants were asked for their perception and characterization of higher education internationalization, as well as the individual factors that shape internationalization, at both their home institutions and in institutions of higher education across the country. Administrators and faculty had similar interview protocols, while government and NGO employees were asked questions more tailored to their agency's activities. In some cases (at least seven), the interviewees were known to have been involved in an international student or faculty mobility program themselves; these interviewees were asked specific questions about how their international experience affected their current duties as instructors and administrators.

The interviews were conducted either in person or via Skype and were recorded. In most cases, participants chose to be interviewed in English, due to their comfort with the language and an understanding that the research was targeted for an audience beyond Georgia; in a few cases, interviews were conducted in Georgian language and translated by one of the authors. The interviews were transcribed and coded using an inductive coding strategy. Furthermore, we reviewed documents recommended by the interviewees (approximately 15), and those that influenced our analysis are referenced in this paper. From the interviews and document review, major themes were identified, and quotes that elucidated these themes are included in this paper.

\section{Key Findings}

In our examination of higher education internationalization in Georgia, we found that Georgian faculty, instructors, and administrators are familiar with and esteem internationalization efforts and cite numerous positive benefits. Interviewees cited three main engines driving internationalization efforts in the country: 1) western influences, 2) national university accreditation processes, and 3) faculty and students returning from abroad. Notably, the effectiveness of implementation is perceived quite differently among faculty and staff, with interviewees agreeing there is no unified effort to internationalize higher education. In addition, interviewees identified two areas where they anticipate growth and increasing influence in the future: foreign students enrolling in Georgian universities and joint degrees. Each of these topics is explored in detail in this section. 


\section{Institutional responses identified as constituting internationalization}

On the whole, interviewees stated that internationalization is important for their universities, although their definitions of the phenomenon ranged considerably and were often vague. One interviewee called the "need to internationalize" a "no-brainer." Another interviewee said that there has been tremendous change in terms of international partnerships, curriculum, and exchanges since Soviet times, when internationalization was, in the interviewee's opinion, "very close to zero." Furthermore, respondents noted that any foreign collaboration - including with countries in the new eastern European Union "neighborhood zone" ${ }^{9}$ and other post-Soviet states - was considered an equal international partner, although partnerships and exchanges with European or North American countries were highlighted more often in the interviews.

When asked about the characteristics of Georgian internationalization, respondents most frequently reported two main activities in which Georgian universities were involved: 1) the internationalization of teaching and learning, and 2) cross-border mobility of students and faculty. Interviewees also listed additional characteristics: establishing joint and dual degrees between Georgian and foreign universities, reforming the quality assurance system to meet international standards, offering more classes in English (with a few degrees at private universities being taught only in English), availing students of a wider array of exchange opportunities, conducting joint research between Georgian and foreign faculty, and increasing access to the "global society of knowledge" for Georgian students and academics.

\section{Perceived benefits of internationalization}

For most interviewees, internationalization was deemed important because it closely aligned with notions of quality. Georgian respondents noted that through various international efforts, university faculty, staff, and students had opportunities to increase their knowledge and improve their skills. Interviewees also suggested that internationalization contributes to the sharpening of faculty's expertise and the production of better quality teaching and learning materials. Furthermore, several faculty and instructors noted that through international partnerships, they learn new topics and pedagogical styles that improve their own courses' overall quality. In one example, an interviewee mentioned sending his syllabi to western colleagues for input and advice.

\footnotetext{
${ }^{9}$ Other countries in the eastern European Neighborhood Policy zone include Armenia, Azerbaijan, Belarus, Moldova, and Ukraine.
} 
A second perceived benefit of internationalization efforts is research and other academic partnerships between Georgian and overseas faculty and students. Faculty, especially those who had participated on a mobility program, highlighted co-authored papers, joint conference presentations, or current research projects with partners abroad, primarily in Europe or the United States. In a specific example, an interviewee highlighted how her studies in the United States allowed her to establish a close relationship with a practicum supervisor, and together they had set a multi-year research agenda that had received funding from the supervisor's university. Another interviewee reported that while attending international conferences, he focused on establishing connections with overseas faculty to conduct research and publish together.

With such internationalization projects underway, Georgian faculty, instructors, and administrators believed their universities are more competitive on the international market. This viewpoint was most often mentioned by university administrators and government officials and rooted in economic terms. As one interviewee succinctly noted, investments of "human and financial resources" gives a Georgian university a "chance to become a member of the international higher education community" and compete as one, with greater ability to attract international students.

\section{Main forces shaping internationalization}

Interviewees identified three main engines driving internationalization efforts in Georgian higher education: western influences, national higher education accreditation, and faculty and students returning from abroad.

Western influences: One force driving internationalization efforts in Georgian higher education is the European and North American programs aimed at promoting higher education reform. The concepts of educational reform and internationalization are closely linked in many former Soviet Republics, with the latter seen as a technique to "overcome the post-Soviet legacy" (Kushnarenko \& Cojocari, 2012: 134). As such, internationalization is often viewed as a predominantly western concept, embodied in a partnership between universities, with a project often spearheaded and funded by the foreign university (Kushnarenko \& Cojocari, 2012).

Specifically, one driver for many international partnerships and programs in the former Soviet Republics is the European frameworks for higher education partnership. Among these, the European Higher Education Area (EHEA) - a set of agreements that allow national education systems to be more compatible and comparable - is considered by many to be the umbrella initiative for increasing international partnerships between Europe and the former Soviet countries (Heyneman \& Skinner, 2014). Although the EHEA was ratified in 2010, the "Bologna Process" started the European organizational efforts a 
decade before, and Georgia signed on in 2005. Joining the Bologna Process provided Georgia, like many other post-Soviet states, "a unique opportunity for integration with Europe beyond the traditional spheres of political and cultural co-operation by building close links in higher education" (Glonti \& Chitashvili, 2006: 209).

In line with these western initiatives, several respondents in this study considered internationalization as a system or set of values encouraged by the European Union. They saw the concept as a western invention, and the expectation to follow internationalization activities as requirements of the government's agreement with the Bologna Process or another political arrangement. One interviewee stated it this way:

In Georgia, given that we try to comply with international trends and Bologna... there is stronger emphasis on internationalization aspect of higher education than in previous years [and] there are some regulations that try to achieve to increase the level of internationalization.

Another talked about making their university programs fit "their requirements," meaning those set by the European Union.

However, there is an argument to be made that Georgia was distinct among its post-Soviet neighbors, as it had been assertive in building European - and North American partnerships before joining Bologna. As Jawad (2005) argues, Georgian education was on course to become more "European" before Georgia joined the Bologna Process, largely due to the Saakashvili government's educational reform initiatives. Moreover, the impact of Saakashvili's break from the Soviet past and alignment with western education can still be felt today. As Dobbins and Khachatryan (2015) recently noted,

We could not discern any major Russian influence over contemporary Georgian higher education. In fact, the opposite has taken place: Georgia has perhaps overzealously endeavored to purge itself of Soviet legacies and Russian influence by adopting numerous neo-liberal steering elements (p. 203).

National higher education accreditation: A second engine of internationalization widely cited by respondents is the Government of Georgia's higher education accreditation process. According to the Accreditation Standards of Educational Programs of Higher Education Institutions issued by the Ministry of Education and Science, "The institution is oriented on internationalizing teaching, scientific work and employment of its graduates" in order to meet national accreditation standards (Ministry of Education and Science of Georgia, 2015b). ${ }^{10}$ In addition, the Government's National Center for Educational Quality

\footnotetext{
10 The higher education accreditation review happens every five years. At the time of writing, new legislation, with changes to the characteristics and requisites for accreditation, is under review by the Georgian Parliament. In evaluating universities, the Georgian government often relies on overseas experts, hoping for a committee with both unbiased review and familiarity with international standards.
} 
Enhancement (2015) also notes that universities should promote "mobility of student and staff, joint educational programs and cooperation in the frames of different research projects" (para. 1). Thus, for many university administrators, the government's inclusion of these elements of internationalization in the state's accreditation process emphasizes both a call for attention to, and action for, internationalization efforts. Adherence to all of these principles is not a necessary condition for university program to be accredited. Instead, these attributes are included to signal that the government values them as part of quality education.

As internationalization is included in the guidelines for accreditation, university administrators see internationalization as more than just a good idea to enhance the competitiveness of Georgian higher education. They deem internationalization as part of a recommended protocol to keep the university running. According to the study's participants, Georgian universities will do "in the first place what is required of them according to the [guidelines] of the state accreditation and authorization standards." One interviewee noted that because of accreditation, her institution focused on strategies to enhance the teaching of "these international perspectives and components" over other internationalization efforts, such as joint research in the humanities or social sciences with overseas partners.

Faculty and students returning from abroad: The third driving force behind Georgian higher education internationalization efforts that emerged from our interviews is the contributions made by faculty and students who studied overseas and returned home. This process is made possible by the notable high rate of return of Georgian students. ${ }^{11}$

Although the exact number of students and faculty participating in overseas exchange is unknown, the popularity of foreign study can be captured in a few statistics. First, according to the interviewees in this study, Georgia has been very active as a partner with the Erasmus+ program (formerly TEMPUS) ${ }^{12}$, the coordinating program that supports cross-border academic exchanges and research among European countries and their partners. In a 2015 report paraphrased by government administrators, Georgia was ranked in the top 10 among 74 participating countries for the number of sending students and faculty. Second, according to the UNESCO Institute of Statistics (2016), nearly 10,000 Georgian students studied outside of their country in 2013 (the most recent data

\footnotetext{
${ }^{11}$ According to research by one of the paper's authors, Georgia has a high rate of return of international scholarship recipients when compared to nearby Moldova (Campbell, 2016).

12 According to the European Commission (2015), "Tempus-like activities, namely capacity building activities, have become part of a new cooperation programme called Erasmus+" starting in 2014.
} 
available), which is approximately $10 \%$ of the estimated total student population. ${ }^{13}$ Third, according to Chankseliani (2016), Georgia has the fourth highest outbound mobility ratios of 14 post-Soviet states, with the most popular destination countries being (in order) Russia, Germany, Armenia, the United States, and France. However, after speaking with various government officials, it is not clear if student mobility figures are accurate, as government offices have reported that there is no unified mechanism for capturing student and faculty mobility data. As one example, statistics offices from different government agencies noted there is no mechanism to collect data on self-funded students who pursue degrees abroad.

In addition to the Erasmus+ coordinating program, international scholarship programs may have also contributed to the number of Georgian students abroad. As part of aid packages following the collapse of the Soviet Union, foreign governments and private foundations like the Open Society Institute provided overseas scholarships for Georgian students. One of the most popular programs, the U.S. government-sponsored Edmund S. Muskie program, has provided support for more than 360 Georgian students to pursue Master's level study in the United States since 1994 (IREX, 2015). In the past decade, a bulk of the funding for overseas higher education scholarships has moved from international donors to the Georgian government and private funders. For example, the Prime Minister's Office has developed a program to provide academic scholarships in priority public service fields (Government of Georgia, 2014). One government representative who participated in our study estimated that another 1,000 students annually were studying outside the country, fully or partially funded by international or domestic scholarships.

When Georgian faculty and students go abroad, they are exposed to alternative education pedagogies, additional disciplines and new specializations, and cutting-edge research methods and discoveries. They bring this newfound knowledge and experience back with them to their universities, sharing it with their colleagues in various ways, such as conducting international research, proposing new courses or degrees, or seeking overseas institutional partnerships.

\section{Perceived effectiveness of implementation}

Collectively, interviewees had mixed opinions on whether various internationalization efforts in the country resulted in the intended effects. On the one hand, interviewees deemed that various programs - in particular, faculty and student mobility programs -

\footnotetext{
13 Most individuals enrolled in Georgian higher education are studying in Tbilisi and likewise, the bulk of students who participate in the Erasmus+ mobility programs attend one of these universities in the capital city (Erasmus Student Network Tbilisi ISU, 2015).
} 
had increased the overall quality of higher education in Georgia and that these changes were embedded in policy and practice. The first example of this is faculty who studied abroad and then returned to develop new degree programs and courses. In one case, students with American graduate social work degrees noted their role in helping to develop the field of social work in Georgia - an academic field that was "virtually nonexistent" in the post-Soviet world twenty years ago (Watkins, 2013). Upon completing their international scholarship program requirements, Georgian graduates formed the Georgian Association of Social Workers and through this organization, designed social work degree programs at two national universities and teach there today (Georgian Association of Social Workers, 2015).

In addition, faculty returned from overseas studies to introduce internationalized curriculum and share new pedagogies. One instructor noted that he teaches in the "American way," promoting class discussion, encouraging his students to identify multiple answers to large problems, and designing homework assignments that spur critical thought. He said that despite his heavy teaching load, he is still proposing new courses, although he often has difficulty finding relevant texts in the Georgian language.

Moreover, faculty and student mobility transcends beyond the teaching and learning in Georgian classrooms to also influence international research partnerships. Respondents indicated that the student mobility among faculty and graduate students often led to partnerships for research. These connections appear to be paying off for Georgian researchers. A government official reported, based on a study the paper's authors could not access, that approximately $80 \%$ of the science, technology, engineering, and mathematics (STEM) research published by Georgian academics also included an overseas research partner.

Georgian students who return from abroad may also have a powerful effect on Georgian internationalization efforts in terms of demanding greater quality. Interviewees noted that these individuals return to Georgian campuses and compare the educational experiences, "are more demanding to their home universities," as they expect the same level of teaching and learning as what they experienced abroad. One interviewee stated that Georgian students who studied abroad are "agents of change" and are "not afraid of accepting new standards." Recently, Georgian students held a protest outside the Ministry of Education and Science, demanding higher quality in Georgian institutions.

However, not all programs with internationalization goals are perceived to be effective. In this study, a majority of respondents noted that the government or their own institutions provided little guidance on the definition, components, or strategies of internationalization, or exemplary models of internationalization at the university level. Professors and instructors were particularly vocal, with some faculty noting that no one 
requires them to incorporate global examples or foreign perspectives into their curricula, test or build their cross-cultural competencies, or state specific internationalization learning outcomes. One university administrator suggested that his university had a robust student and faculty mobility scheme, while a faculty member at the same university suggested the approach to internationalization was "quite sporadic and varies from faculty to faculty." Other respondents noted that there are no "specific indicators in accreditation standards" to assess their university's efforts in encouraging student and staff mobility, few suggestions for how to count foreign classes for Georgian university credits, and no decisive guidelines on establishing international joint or dual degree programs.

In this context, interviewees noted that, while the number of international projects is quite large, various efforts are not connected on a national level. Some respondents characterized efforts as "non-systemic" or "superficial." One interviewee noted, "There are no concrete action plans or implementation strategies among Georgian universities to accomplish internationalization." Despite this lack of guidance and coordination, several interviewees suggested that internationalization was happening - even excelling - in Georgian higher education but in an "organic" or casual way. One interviewee summarized the process by saying it "is not managed, but it happens anyhow."

On the whole, most respondents agreed that Georgia is moving in the right direction by learning as they go. Most interviewees also believed that with increased internationalization efforts comes greater quality of higher education in the country. Several respondents acknowledged the leadership of the Ministry of Education and Science in recently recognizing that additional guidelines would be helpful to the accredited universities and one government official interviewed noted that the Ministry in in the process of responding to this request.

\section{Future opportunities for internationalization}

Interviewees identified two areas that they believe could be significant for Georgian higher education internationalization efforts in the near term.

International students in Georgia: The first area is international students coming to study in Georgia, with more students enrolling in degree programs every year. Most of the international students are from nearby countries of Azerbaijan, Turkey, and Iraq; the South Asian countries of India and Sri Lanka; and the African continent, primarily Nigeria. Most of these students seek degrees in undergraduate programs offered in English, especially in the medical or hard science fields. Few European Union or North American students select Georgia for their host country, with recent data showing that approximately $70 \%$ of Europeans coming to Georgia through the Erasmus+ Program are 
academic staff and not students (Glotni, L., personal communication, February 6, 2016). According to the National Statistics Office of Georgia (2015), 4,780 foreign students studied in private and public Georgian higher educational institutions. According to one government official interviewed for this study, the number of foreign students seeking higher education in Georgia is increasing annually, with approximately $5 \%$ of the undergraduate student body currently being international students.

Perceptions of the role of international student population in higher education internationalization efforts are quite divergent among participants in this study. On the one hand, international students are seen as important contributors to Georgian classrooms. One interviewee noted, sending Georgian students abroad is important, yet "to host international students, it will [be a] bigger effect because then Georgian students will have contact with this international student and they will get some more international perspective." On the other hand, many participants noted that the chief contribution of international students was not to their host university classroom but to the Georgian economy in terms of tuition payments and living costs. Moreover, a few suggested that the Georgian government is concerned about students from certain countries being involved in criminal activity, and worried about the burden placed on host universities of additional screening of applications and lengthy visa procedures. Anecdotal evidence suggests that the foreign students are not well integrated with Georgian students either in the classroom or socially and that they typically leave Georgia following degree completion. From these comments, it appears that international students' role in internationalizing the university is not yet widely accepted at many Georgian universities.

Dual and joint degrees: A second growth opportunity for internationalization in Georgian higher education is the recent establishment of joint and dual degrees. More than just exchange programs, these degrees allow students access to quality foreign education while completing a majority of their studies in Georgia. In some cases, students study at campuses in both countries and receive certificates from two universities upon graduation. In one example, three Georgian universities partnered with San Diego State University in the United States to provide undergraduate degrees in STEM fields (Price, 2014). At the time of writing, the Georgian government and university partners were negotiating joint graduate degrees and several international research projects in the STEM fields. To support the growth of these programs, new legislation on joint, dual, and multiple degrees with foreign universities is currently being proposed.

\section{Conclusion}

This study examined how Georgian university faculty, instructors, and administrators and government and NGO administrators characterize internationalization within the 
Georgian higher education context. In many ways, the Georgian context is similar to other national cases, as it includes a variety of approaches and activities at the system-wide, institutional, and individual levels (Altbach \& Knight, 2007); multiple definitions and characteristics of internationalization are common (Knight, 2012); and there is little consensus on the best strategies to promote it (Cross, Mhlanga, \& Ojo, 2011; Warwick \& Moogan, 2013).

Moreover, our findings support some of the key points made in another study examining internationalization efforts in the similar, post-Soviet state of Moldova. As Kushnarenko and Cojocari (2012) found, student and faculty mobility and academic exchanges are central characteristics to internationalization efforts in small post-Soviet Republics. We also noticed that some of our respondents share similar opinions of internationalization as a predominantly western concept.

On the other hand, this study highlighted a few items that make the Georgian case distinct from Moldova, and perhaps other neighbors as well. First, the Georgian government has incorporated the notion of internationalization into its accreditation process, thereby indicating that international programs and partnerships signal quality in higher education. Second, with the availability of and participation in international scholarship programs and a corresponding high rate of return, many Georgian faculty and students have parlayed their international experience to create new programs, partnerships, and curricula that, in turn, have contributed to internationalization efforts at home. Third, Georgian interviewees noted that both international students and joint degrees are likely sources of future progress in internationalization. Neither of these initiatives was mentioned at length by Kushnarenko and Cojocari (2012) in their examination of the Moldova case.

Finally, the findings in this paper allow us to suggest four points for further research or policymaking considerations that are specific to Georgia. First, if internationalization is considered an important characteristic of Georgian higher education, the government or university leadership should develop and disseminate a clear definition of the concept in the Georgian context. This would include identifying specific components, setting benchmarks, and recommending strategies to achieve them. According to this research, such guidelines would be especially useful to those university administrators who are seeking to meet accreditation standards. Furthermore, by providing a framework for internationalization, leaders can help boost internationalization efficacy and output, instead of leaving it to "happen organically."

Second, this study included perspective from 18 individuals from three universities, the Georgian government, and other organizations working in Georgian international higher education - all based in Tbilisi. Notably, few interviewees mentioned examples from 
institutions or organizations outside the capital city. Moreover, there is almost no data available on internationalization efforts in the regions of Georgia. (One exception is data collected by ERASMUS+ that shows participation in mobility programs is lower for those outside of Tbilisi (Erasmus Student Network Tbilisi ISU, 2015).) Therefore, additional research could illuminate the perceptions and forces driving Georgian internationalization in the regions, and these findings could be compared to our research to provide a deeper and broader understanding of Georgian higher education internationalization.

Third, data on inbound and outbound student and faculty mobility are not collected systematically and are not unified, therefore limiting the potential for accurately charting and monitoring internationalization efforts. Currently, student mobility data appears to be primarily collected based on program, with no shared definition of terms across programs and certain populations (e.g., self-funded students) being neglected. With clear guidelines and systemic data collection, the Ministry of Education and Science, educational organizations, and researchers would strengthen their ability to produce accurate reports on the rate of student mobility - identified in this study as a significant indicator for internationalization in the country. This in turn would support current, and potentially foster additional, internationalization efforts.

Fourth, this study also indicates that hosting foreign students is one area in which Georgian universities can increase their internationalization efforts in the future. At this point, Georgian universities give great attention to the income-generating potential of foreign students. However, university hosts could be persuaded to widen this view and establish ways to capitalize on their contributions to campus internationalization (Urban \& Bierlien Palmer, 2014). Developing a strategy to better understand and support the increasing number of international students will likely assist Georgia in its higher education internationalization efforts, and in turn, attract more foreign students to the country.

\section{References}

Altbach, P. G., \& Knight, J. (2007). The internationalization of higher education: Motivations and realities. Journal of Studies in International Education, 11(3-4), 290-305.

Campbell, A. (2016). International scholarship programs and home country economic and social development: Comparing Georgian and Moldovan alumni experiences of "giving back" (Unpublished doctoral dissertation). University of Minnesota, Minneapolis, MN.

Chankseliani, M. (2016). Escaping homelands with limited employment and tertiary education opportunities: Outbound student mobility from post-Soviet countries. Population, Space and Place, 22, 301-316. 


\section{HERJ Hungarian Educational Research Journal Vol 6 (2016), No 1}

Cross, M., Mhlanga, E., \& Ojo, E. (2011). Emerging concept of internationalisation in South African higher education: Conversations on local and global exposure at the University of the Witwatersrand (Wits). Journal of Studies in International Education, 15(1), 75-92.

Dobbins, M., \& Khachatryan, S. (2015). Europeanization in the "Wild East"? Analyzing higher education governance reform in Georgia and Armenia. Higher Education, 69, 189-207.

Erasmus Student Network Tbilisi ISU. (2015). Erasmus region survey 2014-2015 [report]. Retrieved from http://erasmusplus.org.ge/files/publications/3 3 m s s \%20GE0\%202015-ESN-TBILISIISU\%20PDF.pdf

European Commission (2015). The future of the Tempus Programme as of 01/01/2014 [website]. Retrieved from http://eacea.ec.europa.eu/tempus/programme/new_tempus_programme_en.php

Georgian Association of Social Workers (2015). Georgian Association of Social Workers [website]. Retrieved from http://www.gasw.org/

Glonti, L., \& Chitashvili, M. (2006). The challenge of Bologna. In V. Tomusk (Ed.), Creating the European Area of Higher Education (pp. 209-226). The Netherlands: Springer.

Government of Georgia (2014). 78 students will study at leading universities in the world. Retrieved from http://gov.ge/index.php?lang_id=ENG\&sec_id=288\&info_id=43257

Heyneman, S. P., \& Skinner, B. T. (2014). The Bologna Process in the countries of the former Soviet Union: An outsider's perspective. Journal of the European Higher Education Area, 1, 55-71.

IREX (2015). List of Georgian Muskie alumni [data set]. Tbilisi, Georgia.

Janashia, N. (2004). Fighting corruption in Georgia's universities. Academe, 90(5), 43-46.

Jawad, P. (2005). Democratic consolidation in Georgia after the Rose Revolution. PRIF Reports 73. Retrieved from http://www.hsfk.de/downloads/prif73.pdf

Knight, J. (2012). Student mobility and internationalization: Trends and tribulations. Research in Comparative and International Education, 7(1), 20-33.

Kushnarenko, V., \& Cojocari, L. (2012). Internationalization of higher education in Post-Soviet small states: Realities and perspectives of Moldova. Current Issues in Comparative Education, 15(1), 132-144.

Ministry of Education and Science of Georgia (2015a). List of authorized higher educational institutions [website]. Retrieved from http://mes.gov.ge/content.php?id=1855\&lang=geo

Ministry of Education and Science of Georgia (2015b). Accreditation standards of educational programs of higher education institutions [document]. Retrieved from http://www.eqe.ge/res/docs/2014120419274749836.pdf

National Center for Educational Quality Enhancement (2015). Internationalisation [website]. Retrieved from http://eqe.ge/eng/static/127/internationalisation

National Center for Educational Accreditation (2006). For quality higher education: Annual report. Tbilisi, Georgia. Retrieved from http://eqe.ge/res/docs/angarishi2006.pdf

National Statistics Office of Georgia (2015). Geostat: Number of students studying abroad and foreign students [data set]. Retrieved from http://www.geostat.ge/?action=page\&p_id=205\&lang=geo 


\section{HERJ Hungarian Educational Research Journal Vol 6 (2016), No 1}

Price, M. (2014, July 18). SDSU announces partnership with nation of Georgia. Retrieved from http://newscenter.sdsu.edu/sdsu_newscenter/news_story.aspx?sid=75074

Quigley, K. F. F. (1997). For democracy's sake: Foundations and democracy assistance in Central Europe. Philadelphia, PA: Woodrow Wilson Center Press.

Saakashvili, M. (2006). The way forward: Georgia's democratic vision for the future. Harvard International Review, 28(1), 68-73.

Sharvashidze, G. (2005). Private higher education in Georgia. New trends in higher education: UNESCO International Institute for Educational Planning Report. Retrieved from http://unesdoc.unesco.org/images/0014/001405/140561e.pdf

Silova, I. (2008). Championing open society: The education logic of the Soros Foundation Network. In I. Silova \& G. Steiner-Khamsi (Eds.), How NGOs react: Globalization and educational reform in the Caucasus, Central Asia and Mongolia (pp. 43-80). Bloomfield, CT: Kumarian Press, Inc.

UNESCO Institute of Statistics (2016, January 31). Education: Outbound internationally mobile students by host region [data set]. Retrieved from http://data.uis.unesco.org/index.aspx?queryid=169

Urban, E. L., \& Bierlein Palmer, L. (2014). International students as a resource for internationalization of higher education. Journal of Studies in International Education, 18(4), 305-324.

Warwick, P., \& Moogan, Y. J. (2013). A comparative study of perceptions of internationalisation strategies in UK universities. Compare: A Journal of Comparative and International Education, 43(1), 102-123.

Watkins, T. P. (2013, March). A foundation's perspective: How the Social Work Fellowship Program created change in the Republic of Georgia. Presentation at the Comparative and International Education Society, New Orleans, LA. 